\title{
SELF MANAGEMENT PROGRAM MENINGKATKAN KOPING, NIAT DAN KEPATUHAN BEROBAT PASIEN PJK
}

\author{
(Self Management Programme Improve Coping, Intention, and Medication Adherence in \\ Patients with Coronary Heart Disease)
}

\author{
Hanim Mufarokhah", Suhartono Taat Putra*, Yulis Setiya Dewi* \\ *Fakultas Keperawatan Universitas Airlangga \\ Email: h4n.nimozaghi@gmail.com
}

\begin{abstract}
ABSTRAK
Pendahuluan: Manajemen penyakit jantung koroner (PJK) memerlukan pengobatan seumur hidup. Keberhasilan pengelolaan PJK membutuhkan koping efektif, niat dan kepatuhan berobat dari pasien PJK. Tujuan penelitian ini untuk menjelaskan perubahan koping, niat, dan kepatuhan minum obat pada pasien dengan PJK setelah memberikan program manajemen diri di RSUD Jombang berdasarkan Teori Perilaku Direncanakan. Metode: Desain penelitian adalah quasy exsperimental pretest-posttest group design dengan jumlah sampel 28 secara konsekutif sampling. Variabel independen yaitu self management program dan variabel dependen yaitu koping, niat, kepatuhan berobat. Data dikumpulkan dengan menggunakan kuisioner dengan mengukur tingkat koping, niat dan kepatuhan berobat. Uji statistik yang digunakan adalah mann whitney, wilcoxone signed rank dan t-test. Hasil: Hasil penelitian menunjukkan bahwa 1) program pengelolaan diri meningkatkan tingkat mengatasi pada pasien dengan $\operatorname{PJK}(\mathrm{p}<0,001), 2)$ program manajemen diri meningkatkan tingkat niat pada pasien dengan PJK ( $\mathrm{p}<0,001)$, 3) program manajemen diri meningkatkan tingkat kepatuhan pengobatan pada pasien dengan PJK ( $p<0,001$ ). Diskusi: Untuk mengubah sebuah perilaku membutuhkan perbaikan tingkat koping dan niat. Hal ini sesuai dengan Teori Perilaku Direncanakan bahwa perubahan perilaku dipengaruhi oleh sikap terhadap perilaku, norma subjektif, kontrol perilaku yang dirasakan, dan niat.
\end{abstract}

Kata kunci: self management program, koping, niat, kepatuhan berobat, penyakit jantung koroner

\begin{abstract}
Introduction: Management coronary artery disease required lifelong treatment. The successful management of CHD requires efective coping, intention and medication adherence of CHD's patients. This study aimed to explain the changes of coping, intention, and medication adherence in patients with CHD after giving self management programme in RSUD Jombang based on Theory Planned Behavior.Method: This study used a quasy experimental pretest-posttest control group design and 28 respondens selected by consecutive sampling. Independent variable was self management programme while dependent variables were coping, intention, medication adherence. Data were collected by using questonnaires measuring coping level, intention and medication adherence. The statistical test used was Mann Whitney, Wilcoxone Signed Rank and $t$ Test. Result: The result showed that 1) self management programme improve the level of coping in patients with CHD ( $p<$ $0,001), 2)$ self management programme improve the level of intention in patients with $C H D(p<0,001), 3)$ self management programme improve the level of medication adherence in patients with CHD ( $p<0,001)$. Discussion: To change a behavior requires improvement of coping and intentions. This is in according to the Theory of Planned Behavior that behavior change is influenced by the attitude toward the behavior, subjective norm, perceived behavioral control and intention.
\end{abstract}

Keywords: self management program, coping, intention, medication adherence, coronary heart disease

\section{PENDAHULUAN}

Ketidakpatuhan berobat sangat umum terjadi pada pasien penyakit jantung koroner (American Heart Association 2014). Pasien penyakit kronis yang tidak patuh dalam pengobatan pada akhirnya akan diikuti oleh berhenti melakukan pengobatan. Niat berobat ikut mempengaruhi ketidakpatuhan berobat. Pemberian informasi efektif oleh petugas kesehatan mempengaruhi kemampuan koping pasien penyakit jantung koroner untuk melakukan perawatan diri di rumah.

Sekitar 35\% kematian di Indonesia disebabkan oleh penyakit jantung. Menurut
Federasi Jantung Dunia, angka kematian akibat penyakit jatung koroner di Asia Tenggara mencapai 1,8 juta kasus pada tahun 2014 . Hasil Riset Kesehatan Dasar tahun 2013 oleh Badan Penelitian dan Pengembangan Kesehatan Kementerian Kesehatan Republik Indonesia menyatakan prevalensi jantung koroner di Indonesia sebesar 0,5\%, dan berdasarkan diagnosa dokter sebesar 1,5\%. Prevalensi jantung koroner di Jawa Timur teridentifikasi $0,5 \%$ dan berdasarkan diagnosis dokter sebesar 1,5\% (Riskesdas, 2013). Berdasarkan data awal diperoleh bahwa pada 2014 jumlah kasus PJK 511 dengan jumlah penduduk 1.217.997 dan prevalensi $0,05 \%$. 
Terjadi pertambahan jumlah kasus baru yaitu kasus pertama kali didiagnosis dan kontrol ke Poli RSUD Kabupaten Jombang pada setiap bulan di tahun 2014. Rerata sebanyak 47 kasus baru tiap bulan dalam kurung waktu Maret 2014-Februari 2015.

Fernandes et.al (2008) mengembangkan self management program pada penyakit jantung koroner dan menunjukkan keberhasilan berupa penerapan program berbasis pada perubahan sumber daya mandiri dengan memberikan pelatihan ketrampilan untuk memodifikasi faktor resiko kesehatan seperti merokok, aktifitas fisik, gaya hidup, dan asupan makanan yang dikonsumsi. Studi pendahuluan yang dilakukan peneliti di Poli RSUD Jombang menunjukan bahwa faktor ketidakpatuhan berobat pada pasien penyakit jantung koroner dipengaruhi perilaku acuh terhadap kesehatan dengan diperkuat informasi dan pengalaman kurang dalam pengelolaan penyakit jantung koroner. Faktor lain mempengaruhi ketidakpatuhan berobat adalah sikap menyembunyikan penyakit yang diderita dari keluarga atau teman terdekat, mengakibatkan dukungan sosial kurang dalam perawatan penyakit jantung koroner. Pemberian pendidikan kesehatan masih belum optimal dan upaya Dinas Kesehatan Kabupaten Jombang terbatas melalui penyuluhan di puskesmas yang tidak dapat menjangkau semua pasien PJK di Kabupaten Jombang.

Berdasarkan Theory of Planned Behavior (TPB) diharapkan perilaku terbentuk karena ada niat (intention) yang ditentukan oleh sikap, norma subjektif dan persepsi individu. Pemberian self management program yang berisi edukasi pengelolaan PJK diharapkan dapat membangun persepsi positif melalui learning process sehingga menghasilkan pemahaman untuk mengubah tingkat awareness pasien terhadap kesehatan dengan perubahan sikap dan norma subyektif pasien PJK dapat menghasilkan koping meningkat dan didukung niat berperilaku sehat tinggi maka terbentuk perilaku sehat yaitu kepatuhan berobat.

\section{BAHAN DAN METODE}

Desain penelitian ini adalah quasy experiment pre post test control group design. Besar sampel diperoleh 28 responden (terbagi menjadi kelompok perlakuan dan kelompok kontrol). Teknik pengambilan sampel menggunakan nonprobability sampling dengan metode consecutive sampling.

Sampel dalam penelitian ini adalah sebagian pasien PJK di wilayah Kabupaten Jombang yang memenuhi kriteria inklusi yaitu pasien baru didiagnosa oleh poli RSUD Jombang pada bulan November-Mei 2015 yang tidak kontrol rutin, umur 36-55 tahun, pendidikan minimal lulusan SD. Kriteria eksklusi diantaranya terdapat keterbatasan baik fisik, mental atau kognitif yang dapat mengganggu penelitian (gangguan penglihatan/ buta, gangguan pendengaran/ tuli, dan dimensia).

Variabel independen pada penelitian ini adalah Self-Management Program dan variabel dependen adalah koping, niat dan kepatuhan berobat. Pengumpulan data menggunakan kuesioner koping berdasarkan Coping Srategies Inventory (CSI) (Tobin 2001), kuesioner niat (intention) disusun berdasarkan Theory of Planned Behaviour Questionnaire, dan kuesioner kepatuhan berobat menggunakan memodifikasi instrument yang dikembangkan oleh Dr. Riegel (2007).

Pre-test dilakukan pada kelompok perlakuan dan kontrol dengan mengukur koping, niat dan kepatuhan berobat. Peneliti memberikan intervensi Self management program pada kelompok perlakuan sebanyak 5 sesi (2x/minggu) selama 2,5 minggu. Tiap sesi dilakukan selama 30 menit. Intervensi dilakukan oleh peneliti sendiri sesuai dengan jadwal yang telah disepakati bersama responden. Metode yang digunakan adalah ceramah, diskusi (tanya jawab) dan konseling yang dilakukan di rumah responden. Setelah semua sesi selesai dilakukan intervensi pada kelompok perlakuan, satu minggu kemudian kedua kelompok diukur koping, niat dan kepatuhan berobat. Data yang diperoleh akan dianalisis menggunakan Paired T test, Wilcoxon Signed Ranks Test dan Mann Whitney U Test dengan nilai signifikansi 0,05.

\section{HASIL}

Jumlah responden antara lak-laki dan perempuan pada tiap kelompok seimbang $(50 \%)$. Mayoritas responden berstatus kawin $(78,6 \%)$ pada kedua kelompok dengan pendidikan terakhir di perguruan tinggi $(42,9 \%)$, status bekerja (50\%), umur $46-55$ tahun $(64,3 \%)$, dan seluruh responden bermukim dengan keluarga. 
Hasil uji statistik semua variabel data demografi antara kelompok kontrol dan perlakuan menunjukkan hasil $\mathrm{p}>0,05$ artinya kelompok perlakuan dan kontrol tidak ada perbedaan atau homogen secara statistik. Dengan demikian, data demografi tidak mempengaruhi hasil penelitian antara kelompok perlakuan dan kontrol dalam penelitian ini.

Tabel. 1 Tabulasi frekuensi kategori koping, niat dan kepatuhan berobat penderita PJK di RSUD Jombang, Juli 2015

\begin{tabular}{|c|c|c|c|c|c|c|c|c|}
\hline \multirow{3}{*}{ Kateg ori } & \multicolumn{4}{|c|}{ Perlakuan } & \multicolumn{4}{|c|}{ Kontrol } \\
\hline & \multicolumn{2}{|c|}{ Pre } & \multicolumn{2}{|c|}{ Post } & \multicolumn{2}{|c|}{ Pre } & \multicolumn{2}{|c|}{ Post } \\
\hline & $\mathrm{n}$ & $\%$ & $\mathrm{n}$ & $\%$ & $\mathrm{n}$ & $\%$ & $\mathrm{n}$ & $\%$ \\
\hline \multicolumn{9}{|l|}{ Koping } \\
\hline Baik & 0 & 0 & 13 & 92,9 & 0 & 0 & 1 & 7,1 \\
\hline Cukup & 2 & 14,3 & 1 & 7,1 & 3 & 21,4 & 4 & 28,6 \\
\hline Kurang & 12 & 85,7 & 0 & 0 & 11 & 78,6 & 9 & 64,3 \\
\hline \multicolumn{9}{|l|}{ Niat } \\
\hline Baik & 0 & 0 & 12 & 85,7 & 0 & 0 & 1 & 7,1 \\
\hline Cukup & 1 & 7,1 & 0 & 0 & 3 & 21,4 & 4 & 28,6 \\
\hline Kurang & 13 & 92,9 & 2 & 14,3 & 11 & 78,6 & 9 & 64,3 \\
\hline \multicolumn{9}{|c|}{$\begin{array}{c}\text { Kepatuahan } \\
\text { Berobat }\end{array}$} \\
\hline Baik & 1 & 7,1 & 12 & 85,7 & 0 & 0 & 1 & 7,1 \\
\hline Cukup & 0 & 0 & 1 & 7,1 & 4 & 28,6 & 3 & 21,4 \\
\hline Kurang & 13 & 92,9 & 1 & 7,1 & 10 & 71,4 & 10 & 71,4 \\
\hline
\end{tabular}

Berdasarkan tabel.1 tingkat koping, niat dan kepatuhan berobat yang dimiliki kelompok perlakuan dan kontrol dalam kategori kurang, yaitu sebesar $85,7 \%$ dan $78,6 \%$ untuk tingkat koping, 92,9\% dan $78,6 \%$ untuk tingkat niat, dan $92,9 \%$ dan $71,4 \%$ untuk tingkat kepatuhan berobat.

Berdasarkan tabel 2 diketahui bahwa uji statistik pairred $t$ test yang digunakan untuk melihat perbedaan nilai koping sebelum dan sesudah pemberian intervensi self management program pada kelompok perlakuan menunjukkan nilai $\mathrm{p}<0,001(\mathrm{p}<0,05)$ yang berarti terdapat perbedaan nilai koping yang signifikan pada responden sebelum dan sesudah intervensi self managemen program.

Pada kelompok kontrol yang tidak diberikan intervensi self management program menggunakan pairred $t$ test didapakan hasil bahwa $\mathrm{p}=0,075(\mathrm{p}>0,05)$ yang berarti tidak terdapat perbedaan nilai koping yang signifikan. Hasil uji independent $t$ test sebelum intervensi self management program menunjukkan tidak ada perbedaan antara tingkat koping penderita PJK di RSUD Jombang pada kelompok perlakuan dan kelompok kontrol dengan nilai $\mathrm{p}=0,772$.
Tabel. 2 Tabulasi rekapitulasi hasil uji beda dari koping, niat dan kepatuhan berobat penderita PJK di RSUD Jombang, Juli 2015

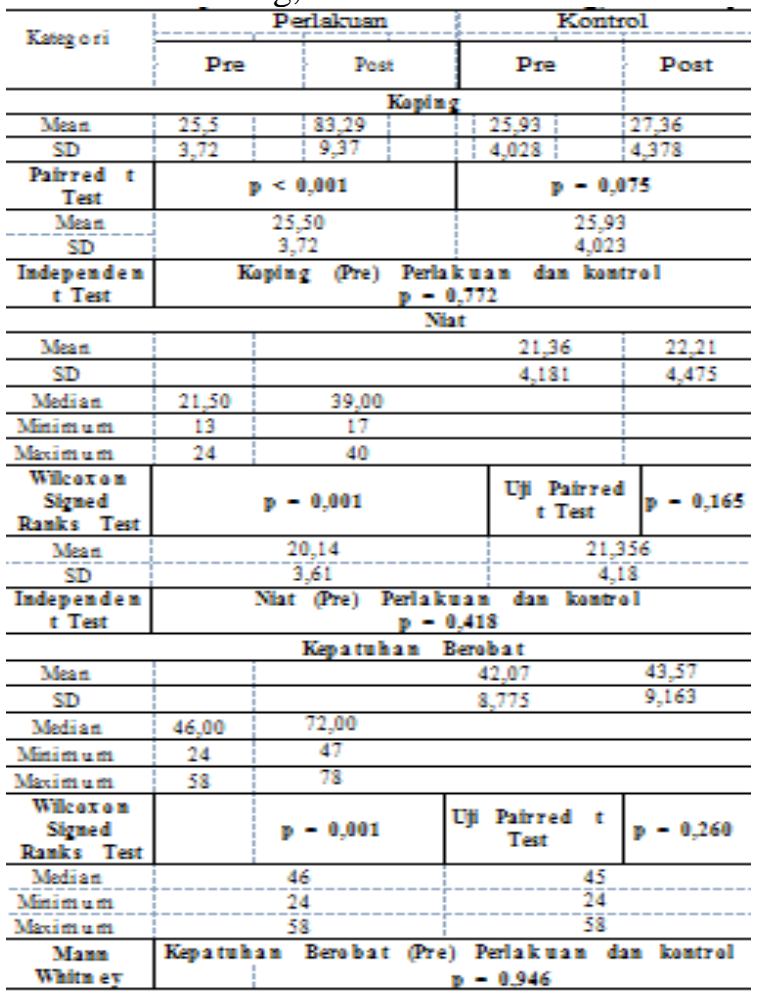

Uji statistik wilcoxon signed rank test yang digunakan untuk melihat perbedaan nilai niat sebelum dan sesudah pemberian intervensi self management program pada kelompok perlakuan menunjukkan nilai $\mathrm{p}=0,001(\mathrm{p}<$ 0,05 ) yang berarti terdapat perbedaan nilai niat yang signifikan pada responden sebelum dan sesudah intervensi self managemen program. Pada kelompok kontrol yang tidak diberikan intervensi self management program menggunakan pairred $t$ test didapakan hasil bahwa $\mathrm{p}=0,165(\mathrm{p}>0,05)$ yang berarti tidak terdapat perbedaan nilai niat yang signifikan. Hasil uji independent $t$ test sebelum intervensi self management program menunjukkan tidak ada perbedaan antara tingkat niat penderita PJK di RSUD Jombang pada kelompok perlakuan dan kelompok kontrol dengan nilai $\mathrm{p}$ $=0,418$.

Uji statistik wilcoxon signed rank test yang digunakan untuk melihat perbedaan nilai kepatuhan berobat sebelum dan sesudah pemberian intervensi self management program pada kelompok perlakuan menunjukkan nilai $\mathrm{p}=$ $0,001(\mathrm{p}<0,05)$ yang berarti terdapat perbedaan nilai kepatuhan berobat yang signifikan pada responden sebelum dan sesudah intervensi self 
managemen program. Pada kelompok kontrol yang tidak diberikan intervensi self management program menggunakan pairred $t$ test didapakan hasil bahwa $\mathrm{p}=0,260(\mathrm{p}>0,05)$ yang berarti tidak terdapat perbedaan nilai kepatuhan berobat yang signifikan. Hasil uji mann whitney $u$ test sebelum intervensi self management program menunjukkan tidak ada perbedaan antara tingkat kepatuhan berobat penderita PJK di RSUD Jombang pada kelompok perlakuan dan kelompok kontrol dengan nilai $\mathrm{p}=0,926$. Secara keseluruhan dinyatakan bahwa setelah pemberian self management program terjadi perbaikan tingkat koping, niat, dan kepatuhan berobat yang signifikan pada kelompok perlakuan dan tidak signifikan pada kelompok kontrol.

Tabel. 3 Tabulasi rekapitulasi hasil uji delta kategori koping, niat dan kepatuhan berobat penderita PJK di RSUD Jombang, Juli 2015

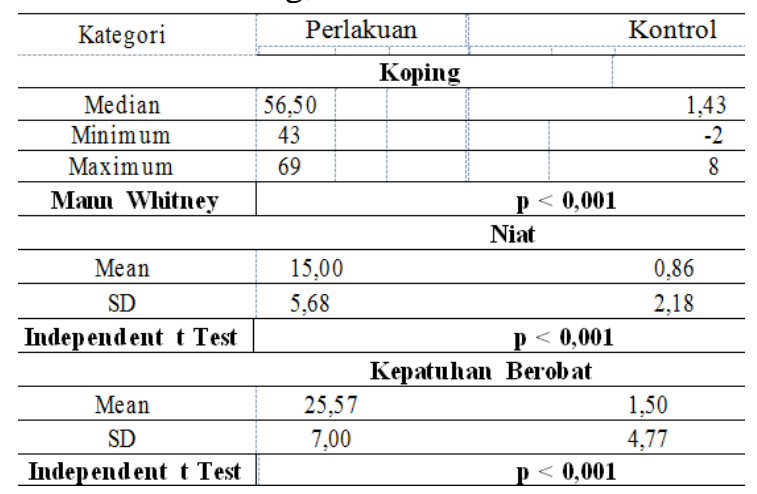

Analisis perbandingan efektifitas self management program terhadap perubahan nilai koping pada kedua kelompok dianalisis menggunakan mann whitney test, niat dan kepatuhan berobat pada kedua kelompok masing-masing dianalisis menggunakan independent $t$ test, didapatkan hasil $\mathrm{p}<0,001$ $(\mathrm{p}<0,05)$ yang berarti terdapat perbedaan nilai koping, niat dan kepatuhan berobat antara kelompok perlakuan dan kontrol. Hasil uji statistik yang dilakukan dapat menjawab dan menerima hipotesis pada penelitian ini yaitu self managemen program meningkatkan koping, niat, dan kepatuhan berobat penderita penyakit jantung koroner.

\section{PEMBAHASAN}

Distribusi jumlah responden berdasarkan tingkat koping sebelum intervensi self management program di RSUD Jombang menunjukkan mayoritas mempunyai koping yang kurang, dan tidak ada responden yang memiliki tingkat koping baik. Fakta tersebut sesuai dengan teori bahwa koping tidak efektif dapat timbul dari pengalaman yang baru, belum pernah dicoba dan tidak memiliki pengetahuan yang cukup tentangnya (Kaplan dan Sadock, 2007). Pasien PJK yang menjadi responden dalam penelitian ini merupakan pasien baru didiagnosa PJK oleh RSUD Jombang antara 1-6 bulan. Semua responden mempunyai pengetahuan kurang tentang perawatan PJK.

Berdasarkan teori planned behavior dapat dijelaskan proses yang terjadi bahwa setelah pemberian intervensi self management program mengakibatkan responden kelompok perlakuan meyakini segi positif dan negatif dari perilaku sehat berdasarkan self management program sehingga terbentuk sikap dan reaksi suka dengan metode self management program untuk pengelolaan PJK di rumah (behavioral belief) karena mereka menilai bahwa metode ini sangat bermanfaat (outcome evaluation). Keluarga responden juga mendampingi dan mendukung metode pengelolaan penyakit PJK berdasarkan self management program selama pemberian intervensi. Hal ini dapat mempengaruhi responden untuk menerima informasi yang diberikan oleh peneliti (normative belief) sehingga dimungkinkan meningkatkan motivasi responden untuk mematuhi cara pengelolaan PJK berdasarkan self management program (motivation to comply). Responden yang mengalami perbaikan koping merupakan individu yang mempercayai pengobatan secara medis (controllability) mengakibatkan ada persepsi responden bahwa mereka mampu untuk melaksanakan pengelolaan PJK di rumah seumur hidup (perceived belief). Dengan demikian, hasil penelitian ini sesuai dengan teori TPB.

Distribusi jumlah responden berdasarkan tingkat niat berobat sebelum intervensi self management program di RSUD Jombang menunjukkan mayoritas mempunyai niat berobat kurang, dan tidak ada responden yang memiliki tingkat niat berobat baik. Niat ini ditentukan oleh sejauh mana individu memiliki sikap positif pada perilaku tertentu, dan sejauh mana memilih untuk melakukan perilaku dengan mendapat dukungan dari orang lain yang berpengaruh dalam kehidupannya (Ajzen 2006), dengan demikian penelitian ini sesuai 
bahwa dari sikap positif yang tidak dimiliki responden yang dibuktikan hasil penelitian menunjukan mayoritas responden memiliki koping kurang mengakibatkan niat berperilaku sehat responden kurang.

Penilaian tingkat niat berobat pada kelompok perlakuan mengalami peningkatan yang signifikan dan peningkatan nilai niat berobat dialami oleh semua responden setelah diberi intervensi self management program. Dengan demikian pasien PJK yang telah mendapat intervensi self management program lebih memiliki intensi atau niat berobat lebih tinggi.

Persepsi kontrol (control perception) mempengaruhi niat terhadap perilaku, sehingga persepsi kontrol mempunyai dua fungsi, yaitu 1) sebagai motivator yang secara tidak langsung mempengaruhi perilaku melalui niat, 2) merefleksikan kontrol perilaku nyata dan berhubungan dengan perilaku tanpa melaui niat. Norma subyektif diartikan sebagai faktor sosial yang menunjukkan tekanan sosial yang dirasakan untuk melakukan atau tidak melakukan perlaku berobat (Dharmmesta 1998). Dalam penelitian ini, norma subyektif adalah kelompok referensi berupa keluarga, petugas kesehatan, teman, peneliti (pihak yang memberikan intervensi) yang mampu mendorong pasien PJK mempunyai niat untuk berobat dalam arti melakukan pola hidup bagi penyakit PJK. Sehingga responden yang mendapatkan intervensi self management program mengalami mayoritas mengalami peningkatan niat berobat yang signifikan.

Dalam penelitian ini terdapat 2 responden yang memiliki niat kurang meskipun sudah diberikan intervensi self management program dikarenakan karakteristik individu yang terkesan kurang percaya dengan pengobatan kimiawi dari dokter sehingga responden ini selalu mengkonsumsi obat herbal dan itupun tidak teratur karena responden ini berpendapat bahwa sesuatu yang berlabihan akan membahayakan tubuhnya, meskipun sudah diberikan konseling dengan berdiskusi bersama namun tetap tidak membawa hasil positif untuk meningkatkan niat berobat. Responden yang tetap memiliki niat kurang memiliki karakteristik individu yang terkesan tidak mau menerima pendapat/ informasi orang lain meskipun sudah dibuktikan secara ilmiah. Responden ini berpendapat bahwa selama ini merasa baik dengan pola hidup yang dijalani. Hasil peneitian sesuai dengan hasil penelitian empiris yang menjelaskan bahwa norma subyektif berpengaruh terhadap niat (Dharmmesta 1998). Norma subyektif terbentuk dari keyakinan normatif dan kemauan untuk menuruti kemauan orang lain yang dianggap penting. Keyakinan normatif berkaitan dengan kondisi bahwa individu setuju atau tidak setuju dengan pelaksanaan perilaku (Dharmmesta 1998).

Pada saat sebelum diberikan intervensi berupa self management program, mayoritas responden memiliki kepatuhan berobat kurang. Responden dalam penelitian ini tergolong baru (1-6 bulan) sehingga pengalaman, pengetahuan dan pemahaman tentang konsekuensi yang diakibatkan oleh penyakit jantung koroner masih sangat minim. Sumber daya keluarga para responden yang meliputi penghasilan dan keadaan ekonomi mempengaruhi tingkat kepatuhan berobat karena responden merasa biaya yang dikeluarkan untuk kontrol rutin, kontrol tekanan darah dan kolesterol, harga obat yang tidak tersedia di apotek BPJS juga menjadi pertimbangan pasien PJK dimana sebagian besar responden mempunyai kondisi ekonomi sederhana. Sumber daya masyarakat meliputi jumlah tenaga kesehatan yang memberikan penyuluhan kesehatan di Poli RSUD RSUD Jombang masih minim, serta penyuluhan kesehatan juga belum aktif secara optimal. Dengan demikian tingkat kepedulian akan kesehatan dalam menunjang pengobatan dan perawatan PJK kurang. Hal ini sesuai dengan penelitian (Purwanto 1999) yang menyatakan bahwa pengetahuan berhubungan dengan kepatuhan berobat.

Penilaian tingkat kepatuhan berobat pada kelompok perlakuan mengalami peningkatan yang signifikan dan peningkatan nilai kepatuhan berobat dialami oleh semua responden setelah diberi intervensi self management program. Pada kelompok perlakuan terdapat 2 responden yang tidak mengalami perubahan tingkat kepatuhan berobat yaitu satu responden yang tetap memiliki kepatuhan berobat kurang dan responden yang sejak awal sudah memiliki tingkat kepatuhan berobat baik, serta terdapat satu responden yang memiliki tingkat kepatuhan berobat cukup, dan yang tersisa mengalami perubahan tingkat kepatuhan berobat kurang ke tingkat kepatuhan berobat baik. Hasil penelitian ini sesuai dengan penelitian yang dilakukan oleh Siu et al. (2007) bahwa self management program 
meningkatkan kepatuhan berobat yang dimiliki oleh seseorang dengan penyakit kronis. Pada responden yang mendapatkan intervensi self management program terjadi penerimaan informasi berupa edukasi mengakibatkan terjadi perbaikan persepsi responden tentang PJK melalui learning process sehingga menimbulkan pemahaman. Pemahaman tentang informasi yang diberikan peneliti dapat diterima secara maksimal karena dilakukan di rumah dengan situasi kondisi yang nyaman, serta diperkuat dengan teknik konseling dan diskusi akan mempermudah memberikan feedback yang jelas. Andersen pada tahun 1968 mengembangkan teori bahwa salah satu komponen predisposisi terbentuknya kepatuhan berobat pasien dipengaruhi oleh pengetahuan, sikap dan tekad untuk sembuh dari penyakit yang diderita. Berdasarkan penelitian yang dilakukan oleh Ley dan Spelman pada tahun 1967 dikutip dalam Barlow et al. (2002) bahwa kualitas interaksi antara profesional kesehatan dan klien merupakan bagian yang penting dalam menentukan derajat kepatuhan dan ada kaitan erat antara kepuasan konsultasi dengan kepatuhan.

Responden yang memiliki keluarga yang juga sangat peduli akan kesehatan memberikan kontribusi yang sangat positif dalam mendukung kepatuhan berobat pasien PJK. Kontribusi keluarga dalam biaya dibuktikan dengan beberapa keluarga responden yang membelikan alat pengukur tekanan darah, kolesterol, glukosa darah, dan asam urat, serta beberapa responden yang memberikan perhatian lebih dengan tidak mempermasalahkan keuangan meskipun kondisi keuangan tidak baik karena dari mereka mempunyai prinsip kesehatan adalah segalanya dan uang masih bisa dicari. Kemampuan mengelola diet terutama istri dari pasien PJK sangat berpengaruh dalam pengelolaan kepatuhan diet pasien PJK, yaitu memisahkan antara diet untuk pasien PJK dengan anggota keluarga lainnya. Fakta yang ditemukan dalam penelitian sesuai dengan penelitian Becker et al. (2001) bahwa dukungan keluarga dan masyarakat mempunyai andil yang besar dalam meningkatkan kepatuhan pengobatan pasien. Barlow (2002) menyatakan bahwa keluarga juga memberikan dukungan dan membuat keputusan mengenai perawatan dari anggota yang sakit, serta menentukan keputusan untuk mencari dan mematuhi anjuran pengobatan.

Keyakinan, sikap dan kepribadian juga menentukan kepatuan berobat dengan dibuktikan bahwa pasien PJK yang tidak mempunyai keyakinan dalam pengobatan secara medis maka berakibat pada katidakpatuhan berobat meskipun sudah diberikan intervensi. Responden yang tidak mengalami perbaikan kepatuhan berobat merupakan responden yang juga tidak mengalami peningkaan niat dan koping. Ketidakyakinan individu tentang informasi yang diberikan peneliti dalam bentuk self management program mengakibatkan sikap untuk tidak melakukan perilaku sehat yang diajarkan dalam pengelolaan PJK sehingga tidak mempunyai motivasi mengikuti pandangan peneliti sebagai pemberi informasi. Informasi yang diberikan peneliti dalam self management program tidak dapat mengubah persepsi dua responden tersebut sehingga niat untuk patuh berobat tidak ada. Berdasarkan teori Planned Behavior bahwa perilaku yang dimiliki individu ditentukan oleh keyakinan, sikap, norma subyektif, persepsi dan niat(Ajzen 2005).

\section{SIMPULAN \& SARAN}

\section{Simpulan}

Pemberian self management program dapat meningkatkan tingkat koping pasien penyakit jantung koroner menjadi baik secara signifikan. Perbaikan juga terjadi pada niat dan kepatuhan berobat pasien penyakit jantung koroner di RSUD Jombang menjadi pada level baik.

\section{Saran}

Pemberian pelatihan pada perawat rumah sakit, Puskesmas, maupun kader kesehatan di desa tentang intervensi self management program pada pasien PJK dengan cara menyiapkan modul pelatihan oleh tim managemen rumah sakit sangat diperlukan. Self management program juga dapat digunakan sebagai intervensi keperawatan dalam pengelolaan penyakit kronis/ menahun selama perawatan di rumah dalam bidang keperawatan medikal bedah dan keperawatan komunitas melalui penyuluhan kesehatan pada saat discharge planning pasien di rumah sakit, pada saat kontrol baik di poli maupun pada saat penyuluhan di desa/ kelurahan dalam 
lingkup komunitas yang dilakukan oleh perawat rumah sakit, Puskesmas, maupun kader kesehatan di desa yang telah terlatih.

\section{KEPUSTAKAAN}

Ajzen, I., 2005. Attitudes, personality, and behavior, New York: Open University Press.

Ajzen, I., 2006. The theory of planned behavior. Organizational Behavior and Human Decision Processes, 50(2), pp.179-211.

Association, A.H., 2014. Guidelines for the management of patients with unstable angina/non-st-elevation myocardial infarction-executive summary. Journal American College of Cardiology, 63(22), pp.57-185.

Barlow, J. et al., 2002. Self-management approaches for people with chronic conditions: a review. Patient Education and Counseling, 48, pp.177-187.
Becker, B.E., Huselid, M.A. \& Ulrich, D., 2001. The human resource scorecard: lingking, people, strategy and performance, Boston: Havard Business School Press.

Dharmmesta, B.S., 1998. Theoy of planned behaviour dalam penelitian sikap, niat dan perilaku konsumen. Kelola, 18(vii), pp.85-103.

Purwanto, H., 1999. Pengantar perilaku manusia untuk keperawatan, Jakarta: EGC.

Riegel, B., 2007. Self-care of heart failure index: School of Nursing, Philadelphia: Clair M Fagin.

Siu, A.H.M. et al., 2007. Evaluation of the chronic disease self management program in a Chinese population. Patient Education and Counseling, 65, pp.42-50.

Tobin, D.L., 2001. Coping strategies inventory, New Orleans: Southeastern Psychological Association. 